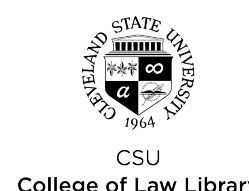

Cleveland State University

College of Law Library

\title{
EngagedScholarship@CSU
}

2-1982

\section{Regulating Pornography: Recent Legal Trends}

\author{
Alan C. Weinstein \\ Cleveland-Marshall College of Law, Cleveland State University, a.weinstein@csuohio.edu
}

Follow this and additional works at: https://engagedscholarship.csuohio.edu/fac_articles

Part of the Constitutional Law Commons, First Amendment Commons, and the Land Use Law Commons

How does access to this work benefit you? Let us know!

\section{Repository Citation}

Weinstein, Alan C., "Regulating Pornography: Recent Legal Trends" (1982). Law Faculty Articles and Essays. 1060.

https://engagedscholarship.csuohio.edu/fac_articles/1060

This Article is brought to you for free and open access by the Faculty Scholarship at EngagedScholarship@CSU. It has been accepted for inclusion in Law Faculty Articles and Essays by an authorized administrator of EngagedScholarship@CSU. For more information, please contact research.services@law.csuohio.edu. 


\section{Regulating Pornography: Recent Legal Trends}

\author{
By Alan Weinstein *
}

Since the Supreme Court's 1976 decision in Young $v$. American Mini Theaters, Inc., 427 U.S. 50 (1976), 28 ZD 329, local governments have been permitted to single out adult bookstores and theaters for special regulatory treatment. ${ }^{1}$ In the wake of Young, many municipalities enacted "pornography zoning" ordinances based on the Detroit dispersion model. Observing this trend in 1978, the Harvard Law REviEw noted that these municipalities were interpreting Young as approving pornography zoning as constitutionally acceptable "in nearly all circumstances." 2 This interpretation seemed incorrect, however, to the Review's editors: "Detroit's pornography zoning was found to satisfy three established First Amendment criteria; future ordinances that restrict the location of adult bookstores and theaters will likely be subject to these criteria as well. ${ }^{\prime 3} \mathrm{~A}$ number of recent lower court cases invalidating pornography zoning ordinances indicate that the REvIEw's prediction was on target.

\section{FIRST AMENDMENT TESTS UNDER YOUNG}

Justice Stevens's plurality opinion in Young set out the First Amendment criteria that the Detroit ordinance - and any future ordinances-would have to satisfy. First, regulations must be motivated not by distaste for the speech itself but by a desire to eliminate its adverse effects. Mere hostility to constitutionally protected speech is an impermissible motive. Second, even properly motivated legislation may be unconstitutional if its severely restricts First Amendment rights. Third, even a properly motivated ordinance with only a limited impact on free expression may be unconstitutional if the municipality cannot demonstrate an adequate factual basis for its conclusion that the ordinance will accomplish its objective of eliminating the adverse effect of adult businesses. ${ }^{4}$ The cases that are discussed here, as well as the better-known Schad case decided by the Supreme Court last

\footnotetext{
*Alan Weinstein is assistant professor of planning and business administration at the University of Wisconsin-Milwaukee and a practicing attorney. Portions of this article were first prepared for the American Planning Association Illinois/Wisconsin Conference, held in Chicago last September. Randall Wondergem assisted with its preparation.
}

1. In Young, the Court upheld Detroit's "dispersion-type" zoning ordinance, which prohibited adult bookstores and theaters from concentrating near each other or near bars, pool halls, and other specified uses. Specifically, the ordinance provided that an adult theater may not be located within 1,000 feet of any two other regulated uses. The "regulated uses" include - in addition to adult bookstores-adult theaters and minitheaters, bars, cabarets, hotels and motels, pawnshops, billiard and pool halls, public lodging houses, secondhand stores, shoeshine parlors, and taxi dance halls. Detroit Ordinance 742-G (Nov. 2, 1972), amending Official Zoning Ordinance of the City of Detroit $\$ \$ 32.007,66.0000,66.0101$ (1962).

2. "Developments in the Law-Zoning," 91 HARv. L. REv. 1427, 1557 (1978).

3. Id.

4. Id. at $1557-59$. summer, show that courts are not at all reluctant to invalidate municipal ordinances that cannot meet these criteria (Schad v. Borough of Mount Ephraim, 49 U.S.L.W. 4597, 33 ZD 254).

In zoning cases, the traditional attitude of courts has been to defer to local officials' assessments of the facts, but in pornography zoning cases courts sensitive to the First Amendment issues at stake have adopted a far more stringent standard of review. It is common in these cases for courts to insist upon a complete record of the evidence available to municipal officials at the time they formulated the ordinance, and some cases have shown judges to be sophisticated analysts of planning issues.

\section{DISPERSION APPROACHES}

The recent invalidation of Atlanta's Adult Entertainment Ordinance, in Purple Onion, Inc. v. Jackson, 511 F.Supp. 1207 (N.D. Georgia 1981), 34 ZD 7, illustrates both the stringency and sophistication of recent court reviews. Atlanta's ordinance, modeled on the Detroit ordinance upheld in Young, was enacted in November 1976. Section 1 of the ordinance set out the findings of fact and statements of purpose in language quite similar to Detroit's. The city council found that adult businesses blight and downgrade property values and have an overall adverse effect on citizens' health and welfare. Thus, the city council found it necessary that adult businesses "be subject to special regulations in order to insure that such uses and the effects thereof will not contribute to the blighting of or the downgrading of the surrounding neighborhood."

The method chosen to control adult businesses was dispersion: certain defined adult businesses were subject to linear restrictions on their location. No adult bookstore, adult entertainment establishment, or adult theater could be located within 1,000 feet of any other such use, or 500 feet of the boundaries of any residential district or property used for residential purposes, or 500 feet of any permanent structure used as a church or place of religious worship. These restrictions, while more stringent than Detroit's, were generally in line with the Detroit scheme, but the Atlanta ordinance also restricted all new adult businesses to three zoning districts and sought to amortize certain existing businesses, both significant departures from the Detroit ordinance.

Much of the testimony at trial dealt with the question of whether or not there were available sites for adult businesses in the three districts to which they were thus restricted: the C-4 Central Business District and $\mathrm{M}-1$ and $\mathrm{M}-2$ industrial districts. In Young, Justice Stevens had suggested that pornography zoning is constitutional only so long as the "market for this commodity is essentially unrestrained." 6 Thus, in the Atlanta case the court was concerned whether the additional locational restrictions of the ordinance were so severe that they would significantly reduce, and possibly eliminate altogether, public access to sexually oriented businesses. The city contended that it was not required to make sure there were sufficient available sites for these adult businesses in the three zones, but it also contended that there were at least 81

5. 511 F.Supp. at 1210.

6. 427 U.S. at 62 
sites adequate for adult entertainment establishments. The court refused to defer to the Atlanta officials' assessment of the facts.

While not examining the 81 sites one by one, the court did carefully review all the maps, documentary evidence, photographs, and testimony regarding site availability. On the basis of that review, the court found that all but 10 of the 81 sites were wholly unacceptable as sites for adult businesses; of those 10 acceptable sites, no more than three or four would be considered by a "reasonably prudent investor" as a possible site for an adult business. " The court's review is notable for its sophistication regarding land use.

The court first found that a few of the 81 sites were unacceptable because they violated one or more of the ordinance's distance criteria. Many other sites were wholly unsuited for retail or commercial use because the lot was too small or because its shape precluded construction of a building of the proper size. One site had an easement through the middle for electric transmission wires. Several sites were 20 to 30 feet below street level, making retail or commercial uses impossible. At least one site was in a floodplain. In several instances, the site was unsuitable because of nearby noxious uses: one site was in the middle of a group of petroleum storage tanks; another was contiguous to a city sewage treatment plant.

Going further, the court found that a large number of the proposed sites were simply unavailable and would remain so for the foreseeable future. Some of the proposed sites were employee parking lots for large, permanent manufacturing facilities. Other sites were occupied by buildings housing substantial businesses. In a number of cases, the ownership or use of the site made its sale to the operator of an adult business highly unlikely: one landowner was the city of Atlanta; another was the Southern Railway, and the court felt that it was unlikely to sell or lease any of its railroad rightof-way for an adult business.

At the time of trial, the court found that there were 42 or 43 sexually oriented businesses in Atlanta and 12 or 13 that offered live entertainment. All of the live establishments except one would be affected by the amortization provision and would be permitted to relocate in only one of the three zoning districts. The other adult businesses presently in zones other than the permitted zones would become nonconforming uses under the ordinance and would face a ban on enlarging, extending, or reconstructing their businesses. Thus, normal attrition would slowly reduce the number of adult bookstores and theaters in districts other than C-4, M-1, and M-2. On the basis of these facts, the court concluded that allowing the ordinance to stand would reduce public access in Atlanta to both live, sexually oriented entertainment and to movies, books, and paraphernalia characterized by an emphasis on sex.

Although the court's finding of restricted access was, by itself, enough to invalidate the ordinance-it clearly violated Justice Stevens's second criterion-the Atlanta scheme suffered from many other faults. The court found the definitions of adult businesses to be substantially overbroad. The ordinance defined "adult bookstore" so loosely that, in the view of the court, the definition would include the federal courthouse and numerous private dwellings. The definition of an

7. In making these findings, the court did not consider either the price of the land or whether the land was presently for sale. adult theater could easily be read to include downtown hotels that offered "adult movies" on cable television in guests' rooms.

The court was also strongly influenced by evidence of an improper motive in enacting the ordinance. Minutes of a meeting of the zoning review board revealed that, in addition to the ordinance's stated purposes, another purpose was discussed: that it would help those citizens disgusted by the conduct of these businesses to "zone them out of business." At that same meeting, an assistant city attorney indicated that the adult zoning ordinance was the "strongest vehicle toward elimination" of adult businesses and the city was "hoping for complete eradication" of adult businesses. The city attorney also stated that the effect of the ordinance would be to reduce the number of these establishments.

Taken together, the evidence of an improper motive, the overbroad definitions, and most critically, the fact that the ordinance would immediately reduce or eliminate public access to live, sexually oriented entertainment and would gradually reduce the availability of erotic books and movies led the court to declare the ordinance void for violation of the First Amendment. Atlanta is appealing the district court's ruling, but, at present, the city is discussing new legislation that would either copy the Detroit ordinance more closely or use the regulation of alcoholic beverages as a means of regulating adult entertainment. ${ }^{8}$

The Atlanta case is not unique. A general pattern is emerging in which courts strike down pornography zoning ordinances that violate one or more of the criteria announced in Young. In CLR Corp. v. Henline, 520 F.Supp. 760 (W.D. Michigan 1981), 34 ZD 59, a federal district court invalidated a pornography zoning ordinance from Wyoming, Michigan, a city of 62,000 adjacent to Grand Rapids. The ordinance, although modeled on the Detroit scheme, had the effect of ensuring that no more than two to four adult establishments could locate in the city, with all the potential sites being located on 2,500 feet of frontage on one road near the western edge of the city. The court also found that the city had failed to provide any legislative history or factual background supporting the need for the ordinance. The city contended that it was unnecessary for it to have a separate legislative history when the experience of Detroit and other cities regarding these ordinances has been so thoroughly documented. The city also sought to apply the distance restrictions of the ordinance in cases where no Wyoming residents were close enough to a potential site to prohibit the location but residents of Grand Rapids were - apparently the first time that distance requirements under the Wyoming zoning ordinance had ever been measured outside of the city's territorial limits. The court ultimately found the ordinance void under the third standard in Young because of the complete failure of the city to assert any state interest to justify the ordinance.

\section{LICENSING AND SPECIAL USE APPROACHES}

Perhaps the best example of special use and licensing procedures operating as prior restraints on free speech is Entertainment Concepts, Inc. v. Maciejewski, 631 F.2d 497 (1980), 33 ZD 129. There, the village of Westmont, a Chicago suburb, amended its zoning ordinance to create a new special use category - adult movies, indoor theaters - and passed a

8. See N.Y. State Liquor Authority v. Bellanca, 69 L.Ed.2d 357 (1981) 
license revocation ordinance that prohibited the exhibition of "obscene" motion pictures. The facts surrounding this legislation are quite illuminating. The plaintiff operated the only movie theater in Westmont. On September 21, 1979, he began advertising "Coming Soon, Adult Movies" on the theater marquee and scheduled the movie Beneath the Valley of the Ultra-Vixens to open on November 9. On October 1, the village passed its special use amendment, which was nothing more than a one-line addition to the list of permitted and special uses in the zoning ordinance.

The court found numerous defects in the two village ordinances. First, the special use ordinance contained no definition of the term "adult movies"; thus the plaintiff did not know whether he had to apply for a special use permit even if he showed only one X-rated or R-rated film. The ordinance also was found to have as its "operative distinction" the content of the movie shown, did not advance any legitimate governmental interest to support the zoning amendment, and gave unbridled discretion to village officials to grant or deny a special use permit. In short, the special use ordinance could satisfy none of the criteria in the Stevens opinion.

The second Westmont ordinance provided for the revocation or suspension of a movie theater's license upon a finding of obscenity by the village's movie review board and the mayor. The movie review board consisted of three Westmont residents who would review motion pictures publicly exhibited in the village "to determine whether or not they are obscene." If a majority of the board found a movie obscene, they would report their finding to the mayor. The mayor would then conduct an "adversary-type hearing" where the movie exhibitor could contest the board's findings. If the movie were found obscene after this hearing, the ordinance provided for a 90-day license suspension for a first offense and permanent license revocation for a second offense. The court found this portion of the ordinance wholly without merit. Noting that a municipality "is not free to adopt whatever procedures it pleases for dealing with obscenity ... without regard to the possible consequences for constitutionally protected speech," the court held the licensing ordinance insufficient in failing to provide adequate procedural protections of speech and in providing the penalty of suspension or revocation.

\section{Special Use Permits}

County of Cook v. World Wide News Agency, 424 N.E.2d 1173 (I1l. App. 1981), 34 ZD 10, is one of the latest in a line of cases in which courts have found that special use procedures applying only to adult businesses are invalid prior restraints on freedom of expression. In World Wide News Agency, an amendment to the Cook County zoning ordinance limited adult bookstores, adult theaters, and adult minitheaters to areas zoned $\mathrm{C}-3$ and made these adult businesses special uses that required the issuance of a special use permit. The ordinance also contained a distance provision: adult businesses could not locate within 1,000 feet of an area zoned for residential use, although this prohibition could be waived if the applicant obtained the approval of 60 percent of the neighbors within 1,000 feet of the proposed use. The combination of the distance provision with the restriction of adult businesses to areas zoned C-3 meant that most locations for adult businesses would have to comply with both the special use and the 60 percent approval requirements. ${ }^{9}$ The Illinois Appellate Court held that these restrictions were an impermissible prior restraint on speech. The court was very concerned with the discretion granted to the county board through the special use provision and the "veto" that neighbors would have over most locations zoned to allow adult businesses.

\section{Business-Licensing Requirements}

Two cases from the Seventh Circuit Court of Appeals illustrate the bounds of constitutionality when adult businesses are subject to licensing requirements. Genusa v. City of Peoria, 619 F.2d 1203 (1980), involved a Detroit-type ordinance that also included licensing, inspection, and employee permit requirements. The court upheld the distance provision in the ordinance and also found that both the requirement of a license and the $\$ 100$ license fee were reasonable adjuncts to the zoning scheme; i.e., it was a way to keep track of adult uses and assure that they complied with the zoning ordinance. But the court struck down the ordinance's requirement that adult businesses undergo a special inspection to ascertain whether they were in compliance with all provisions of the Peoria city code.

The problem here, in the court's view, was that only adult businesses faced the special inspection requirement. To the court, this was an impermissible prior restraint on speech that had as its operative distinction the content of the books or movies that were sold or exhibited on the premises. The court denied that the city could have any legitimate governmental interest in making a special inspection of bookstores with one type of books, while bookstores with other types of books would not be inspected. For similar reasons, the court also invalidated a portion of the ordinance that ordered the police department to conduct a special investigation of applicants for adult business licenses and another that required employees of adult businesses to obtain an employee permit. ${ }^{10}$

By contrast, Chulchian v. City of Indianapolis, 633 F.2d 27 (1980), involved the validity of a general business licensing ordinance. Chulchian, the operator of an Indianapolis theater that showed sexually explicit films, was denied his annual business license on the grounds that there had been numerous arrests on the premises for "illegal, immoral, or obscene conduct" and that neighboring residents considered the theater "to create a nuisance." Chulchian charged that the licensing ordinance, by authorizing the closing of his theater

9. A county official testified that there were approximately 40 to $45 \mathrm{C}-3$ zones in unincorporated Cook County. All but three of these zones were within 1,000 feet of an area zoned residential.

10. See also Wortham v. City of Tucson, 624 P.2d 334 (Ariz. App. 1981) (licensing ordinance impinging on First Amendment rights that gives the licensing authority broad discretion to refuse a permit is unconstitutional prior restraint of those rights); Wendling v. City of Duluth, 495 F. Supp. 1380 (D.C. Minnesota 1980), 33 ZD 160 (imposition of $\$ 500$ annual fee on adult businesses is an unlawful prior restraint, and provisions of general licensing requirements as applied to adult bookstores were unconstitutional for lack of necessary procedural safeguards); Doe v. City of Buffalo, 432 N.Y.S.2d 982 (1980) (unbridled authority of licensing authorities with respect to issuance of license was unconstitutional infringement of First Amendment freedom). The Supreme Court recently upheld a licensing scheme from Minot, North Dakota, that imposed a $\$ 300$-per-device license fee on amusement "devices," but the case had not been reported prior to publication. See Minot v. Central Ave. News, Inc., 308 N.W.2d 851 (N.D. 1981), for the ruling in the court below. 
if he permitted illegal conduct on the premises, was an impermissible restraint on constitutionally protected speech.

The court disagreed, arguing that the ordinance, although it covered theaters, did not regulate them on the basis of content; the ordinance applied to all businesses in Indianapolis. Further, the ordinance required that a licensee know that his conduct was illegal. Although the city of Indianapolis acknowledged that it bore the burden to prove such illegal knowledge, the city also indicated that it would not deny a license because of an isolated incident and conceded that it could not use obscenity convictions to justify the denial of a license.

The court felt that under these circumstances the discretion granted under the ordinance was not boundless and held the ordinance to be constitutional. In the view of the court, the ordinance furthered a legitimate and substantial governmental interest that was unrelated to the suppression of free speech. Chulchian was denied his license for reasons wholly unrelated to speech; the ordinance did nothing more than hold the operator of a business responsible for conduct on the premises of which he had knowledge. Although Chulchian's theater had been denied a license because it had been found to be a nuisance, it was not a nuisance because it exhibited sexually explicit films. Rather, it was a nuisance because there had been a pattern of arrests for illegal activities associated with its operation as a theater.

\section{REGULATING TOPLESS DANCING AND MASSAGE PARLORS}

The stringency of court review of pornography zoning is attributable to the courts' perceived need to safeguard forms of expression protected by the First Amendment where there is widespread distaste for the form of expression itself. When these First Amendment concerns are either absent or are superseded by other constitutional concerns, the outcomes of court reviews are substantially different. Thus, when courts review ordinances that govern massage parlors or regulate live entertainment in establishments serving liquor, the analysis presented above is inappropriate. Massage parlors, while adult businesses, do not have First Amendment protection. Nude dancing is arguably "speech"; the act of bodily massage is definitely not. And, even though it is a protected form of expression, nude dancing and other sexually oriented live entertainment may be regulated in establishments serving liquor under the broad powers granted to the states by the Twenty-first Amendment (Repeal of Prohibition).

\section{Liquor Licensing Approaches}

The Supreme Court has long recognized that a state has absolute power under the Twenty-first Amendment to prohibit totally the sale of liquor within its borders. It is equally well established that a state has broad power under the amendment to regulate the times, places, and circumstances under which liquor may be sold. Ten years ago, in California $v$. LaRue, 409 U.S. 109 (1972), the Court upheld a state's right to prohibit nude dancing in bars under a statute prohibiting acts of "gross sexuality" in establishments serving alcohol. Although agreeing that nude dancing had a certain protected status under the First Amendment, the Court stressed that the added presumption in favor of the validity of state regulation that the Twenty-first Amendment confers required that the regulation be upheld so long as it was not an irrational exercise of the police power.

The Court faced the issue again this past summer in New York State Liquor Authority v. Bellanca, 69 L.Ed.2d 357 (1981). In 1977, the New York State legislature enacted legislation banning topless dancing in bars. The legislation was immediately challenged. In 1980, the New York Court of Appeals ruled that the law amounted to censorship of a constitutionally protected means of expression and that the state had failed to show a governmental interest sufficient to justify the restriction on free expression. The Supreme Court, without hearing argument in the case, reversed the decision. The Court agreed that topless dancing has a certain protected status, but, when liquor regulation is involved, the balance tips in favor of the state. In the Court's view, the law was a rational exercise of the police power based on the legislature's finding that any form of nudity coupled with alcohol in public places results in undesirable behavior and that such behavior can best be prevented by prohibiting nudity in establishments serving liquor.

On remand from the Supreme Court, the New York Court of Appeals last November held that the guarantee of freedom of expression in the New York State constitution served to invalidate the ban on topless dancing independently of the U.S. Constitution and again declared the legislation unconstitutional.

In its first opinion in the case, Bellanca v. New York State Liquor Authority, 50 N.Y.2d 524 (1980), the court of appeals had not found it necessary to consider the New York State constitution, holding that the statute was invalid under the U.S. Constitution. On remand, the majority based its holding on two arguments: first, that there were no legislative findings to support the state's exercise of its authority to ban topless dancing; and second, that, since the New York State constitution contains no provision similar to the Twenty-first Amendment, the state constitution's guarantee of free expression is "undiminished" by other policy considerations and thus serves to prohibit the legislature's ban on topless dancing even when the federal Constitution would not. ${ }^{11}$

11. The majority opinion, however, is far from satisfying. The majority's first argument-the absence of legislative findings-hinges on interpretation of a "Legislative Support Memorandum" that accompanies the topless dancing statute. In the view of the majority, this document is nothing more than "the memorandum of the assemblyman who introduced the bill" and, "[a]lthough his memorandum might perhaps be classified as part of the legislative history, ... there is nothing to suggest that it was adopted by the legislature or otherwise converted into legislative findings. ..." But it was this same memorandum that was quoted with approval by the U.S. Supreme Court in support of its view that, even if explicit legislative findings were required to uphold the ban on topless dancing, they exist in this case. Further, Justice Garbrielli's dissent in Bellanca on remand notes that the memorandum is reprinted in the 1977 New York State Legislative ÁnNUAL, which "provides contemporaneous documentation of legislative intent." Thus, the majority's argument regarding the lack of legislative findings seems strained in the absence of any indication that the legislature was unaware of its own member's memorandum.

The majority's second argument-focusing on the role of the Twenty-first Amendment -is equally strained. The majority argues that because the state constitution contains no equivalent to the Twenty-first Amendment, there is no countervailing constitutional reason to curtail the right to free expression. But, as Justice Jasen notes in his dissent. 'The broad sweep of the Twenty-first Amendment has been recognized as conferring something more than the normal state authority over public health, welfare, and morals," California v. LaRue, 409 U.S. 109, 114 (1972). In short, a state constitution need not contain an equivalent to the Twenty-first Amendment for the force of that amendment to have an effect on judging the constitutionality of state 
Persons familiar with the cabaret business in New York have argued that the case will have little impact. Establishments that have been "using sex to sell liquor" are likely to switch from topless dancing to "wet T-shirt contests" or put "pasties" on their dancers. Establishments that are primarily purveyors of sexually oriented entertainment, on the other hand, have the option of becoming "juice bars." They would then be safely outside the state's regulatory authority.

\section{ZONING APPROACHES}

Massage parlors are treated quite differently from adult bookstores and theaters not only because their activities are not protected by the First Amendment but also because there is a strong historical link between prostitution and commercial establishments that offer body massage by members of the opposite sex. ${ }^{12}$ The most recent development in the regulation of massage parlors has been the use of county zoning ordinances to control these uses.

Two recent Texas cases illustrate the trend: Stansberry $v$. Holmes, 613 F.2d 1285 (5th Cir. 1980), 32 ZD 212, and Harper v. Lindsay, 616 F.2d 849 (5th Cir. 1980). Noting that massage parlors had moved outside city limits to escape regulation, the Texas legislature enacted enabling legislation that empowered counties to adopt regulations governing the operation and location of massage parlors and similar establishments. Harris County (suburban Houston) subsequently adopted regulations that restricted the location of massage parlors by requiring owners to show that their businesses were at least 1,500 feet from certain other uses, including schools, dwellings, and buildings serving alcohol.

In reviewing the subsequent challenges to the ordinance, the court emphasized that its analysis of the regulations was guided only by the traditional standards applicable to zoning regulations. So long as the ordinance was not "arbitrary and capricious, having no relation to the general welfare," it would be upheld. The court then found these regulations "a rational and understandable effort to deal with a perceived evil that affected living conditions in the area," with no discussion of the effects on the businesses as would be required were First Amendment rights at issue.

actions that regulate any aspect of the sale of alcoholic beverages. The majority declined to accept this position, holding that the ban on topless dancing must be justified solely on the basis of the general police power and finding that, under the police power, the ban on topless dancing constituted an impermissible restriction on freedom of expression. However, the majority's finding on this issue is unsupported by the citation of any authority and seems mistaken in view of the authority that Justice Jasen cites for his position that under the "more than normal" police power conferred by the Twenty-first Amendment, the minimal restriction on free expression of a ban on topless dancing must give way to the critical state interest in regulating the sale of alcoholic beverages.

However strained the majority opinion may be, it now stands as law in New York until the legislature chooses to act. Given the majority's holding, a new legislative enactment that bars topless dancing in establishments serving liquor, so long as it is accompanied by an explicit statement of legislative findings, should be upheld.

12. Most land use ordinances that regulate massage parlors, which are usually termed Adult Physical Culture Establishments in the ordinance, define these uses partly by focusing on contact between members of the opposite sex. This is done mainly to avoid characterizing health spas and similar establishments as massage parlors, but New York City officials report a more intriguing reason. Homosexual massage parlors in New York are operated so discreetly that they rarely intrude on neighborhood sensibilities enough to become an issue.

\section{GUIDELINES FOR ORDINANCE DRAFTING}

Taken as a whole, the most recent pornography zoning cases involving restrictions on adult businesses with First Amendment protection-such as theaters and bookstores-show a clear pattern of strong judicial concern with maintaining community access to such businesses. In determining the constitutionality of municipal adult-use ordinances, courts have generally looked to Justice Stevens's opinion in Young for guidance but have also considered Justice Powell's concurring opinion in Young and the majority and concurring opinions in the recent Schad case. The courts now appear to be guided by the following general rules.

First, an ordinance whose effect is to severely restrict the locations available to accommodate adult businesseswhether present or anticipated-will be struck down. Locational restrictions on adult businesses are permissible only if the "market for this commodity is essentially unrestrained." Thus, at minimum, ordinances should not operate to reduce the total number of existing adult businesses in a community or preclude the normal operations of the market in providing new businesses as demand warrants. Further, the presence of adult businesses in neighboring communities to which residents have "reasonable access" will not leave a community free to eliminate such businesses within its own borders.

Second, ordinances whose wording is vague, especially where the definitions in the ordinance make it unclear what is and what is not regulated, will be struck down. A vaguely worded ordinance leaves the business operator uncertain as to whether or not his activities come within the ordinance's prohibitions and thus functions as a prior restraint on freedom of expression.

Third, ordinances that do not develop a factual basis for their restrictions on adult businesses or which do not relate their restrictions directly to recognized zoning purposes will be struck down. Pornography zoning is permitted to have a limited impact on free expression only because it serves other legitimate governmental interests, such as the preservation of neighborhoods. To guard against regulations that are motivated by a distaste for constitutionally protected speech itself, communities must demonstrate the adverse effects associated with the places where the expression occurs and narrowly tailor their restrictions to further the specific governmental interests endangered by the presence of adult businesses.

Fourth, and last, ordinances that grant government officials broad, unbridled discretionary powers to determine whether or not an adult business will be permitted to operate-such as special use permits and licensing provisions-will be struck down. The courts will permit officials discretionary power to close or prohibit an adult business only where their authority stems from an ordinance not directed solely at adult uses and where there are both strict limits on administrative discretion and procedures that safeguard First Amendment rights.

\section{TRENDS}

As a final comment, a recent article in the New York Times Magazine $^{13}$ suggests that adult businesses-and, therefore,

13. Tony Schwartz, "The TV Pornography Boom," September 13, 1981, at 44 . 
the furor surrounding their regulation-may be approaching a rapid decline. The article notes the following: installations of cable television and sales of videorecorders are increasing rapidly; 25 to 50 percent of all prerecorded videocassettes sold are $X$-rated; when $X$-rated movies are offered as a separate feature on cable, the percentage of viewers regularly exceeds 50 percent and goes as high as 95 percent.

Al Goldstein, publisher of ScREW magazine and a pioneer in the adult entertainment business, says in the article: ' $\mathrm{I}$ ' $\mathrm{d}$ hate at this moment to be the owner of a porno theater. Their obsolence is inevitable. Some people say I'm a doomsayer, but I think the technology speaks. X-rated films should never have been seen in theaters anyway. It's O.K. to see a horror film in a theater, but the point of a porno film is to turn you on, and a theater isn't the best place for that. The ideal context is the home."

\section{Planners and the} Unauthorized Practice of Law: A Lawyer's Response

\author{
By Philip J. Tierney*
}

The recent commentary by Stuart Meck entitled "Some Thoughts on City Planners and the Unauthorized Practice of Law" (33 LUL/ZD No. 10 at 6) contains valid criticisms of the legal community's sometimes overly protective view of what constitutes the practice of law. However, the article also contains some disturbing remarks about the lawyer's role in the administrative process. Meck contends that lawyers need not be exclusively entitled to represent clients before planning commissions and zoning boards. He observes that while:

[i]t is true that in complex administrative proceedings legal training and the knowledge of an attorney would definitely be necessary, .. that is not the case here. Boards of zoning appeals are composed of lay persons with no special legal training and often no special training at all. Despite the judicial aura ... conferred upon them, boards are not courts of law. This is not to say that boards should not be subject to reform; indeed, there have been many such proposals. Rather, their procedures are not difficult for a lay representative to grasp, and no license to practice law is required to comprehend them."

It is important to define what we mean by administrative proceedings. In this context, I take the term to mean those proceedings before planning commissions or zoning boards where evidence is presented to meet certain legal burdens of

*Philip J. Tierney is an attorney and chief hearing examiner for Montgomery County, Maryland. proof or persuasion and the applicant seeks to obtain a favorable ruling from the commission or board. I do not take the term to include those preliminary steps that may precede a formal administrative proceeding.

Despite the lay character and informality of administrative proceedings, lawyers perform an indispensable function for clients just by being there. They are there to protect the legal rights of a client. The abuse or denial of these legal rights may occur at unpredictable moments and in the most unlikely situations.

An administrative proceeding, even at the simplest level, involves basic due process rights. Adequate notice and a fair hearing are essential. Many states require opportunity for cross-examination. Knowledge of past administrative decisions and agency adherence to them is critical. Conclusions of witnesses should be based upon well-reasoned testimony. Extraneous or irrelevant evidence should be excluded from the record. The board or commission should conclude the proceeding with written findings of fact and conclusions of law that are based upon evidence of record. A client's representative should be able to recognize these rights and assert them to the fullest benefit of the client. Lawyers are uniquely qualified to identify and enforce these rights. Indeed, lawyers alone possess skills that enable the client to take full advantage of these rights.

A lawyer is not simply a defensive player. He or she is trained to arrange the presentation of evidence in the light most favorable to the client. The lawyer can neutralize or diminish opposition to the client's cause. A lawyer's involvement can make the difference in a close case and provides a valuable insurance policy in not so close cases.

Notwithstanding the benefits of having a lawyer as a representative in an administrative proceeding, they have on occasion represented their clients poorly. In such an event the client has recourse through a malpractice claim or under the strict professional disciplinary codes. An ample body of law protects clients from errant lawyers. This is not the case when the client's errant representative is a nonlawyer.

Many states have already spoken on the issue of nonlawyer representation in administrative proceedings and have rejected the practice. Last year the Maryland attorney general ruled that nonlawyers should not act in a representational capacity in an administrative proceeding (Op. Atty. Gen. Md. 80-637). Despite Meck's skepticism, these rulings are not intended to protect lawyers from competition; rather, they are intended to protect clients from those unqualified to act in a representational capacity.

Legal problems come up in unexpected ways, and lawyers are trained to recognize and handle them. Anything less than representation by counsel only shortchanges the person being represented. Lawyers carry a heavy responsibility in their representational capacity. It is not clear from Meck's article why any sensible nonlawyer would want to assume that burden. 


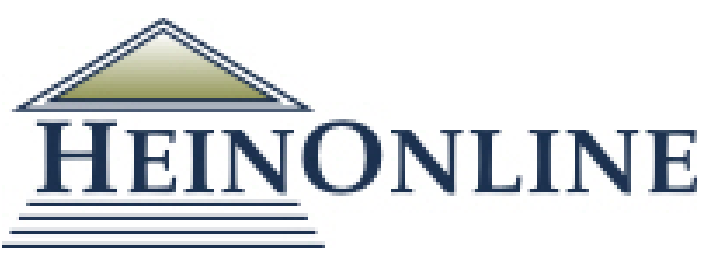

Content downloaded/printed from

HeinOnline

Thu Nov 7 13:55:57 2019

Citations:

Bluebook 20th ed.

Alan Weinstein, Regulating Pornography: Recent Legal Trends, 34 Land Use L. \& Zoning Dig. 4 (1982).

ALWD 6th ed.

Alan Weinstein, Regulating Pornography: Recent Legal Trends, 34 Land Use L. \& Zoning Dig. 4 (1982).

APA 6th ed.

Weinstein, A. (1982). Regulating pornography: Recent legal trends. Land Use Law

Zoning Digest, 34(2), 4-9.

Chicago 7th ed.

Alan Weinstein, "Regulating Pornography: Recent Legal Trends," Land Use Law \& Zoning Digest 34, no. 2 (February 1982): 4-9

McGill Guide 9th ed.

Alan Weinstein, "Regulating Pornography: Recent Legal Trends" (1982) 34:2 L\& Use L \& Zoning Digest 4.

MLA 8th ed.

Weinstein, Alan. "Regulating Pornography: Recent Legal Trends." Land Use Law \& Zoning Digest, vol. 34, no. 2, February 1982, p. 4-9. HeinOnline.

OSCOLA 4th ed.

Alan Weinstein, 'Regulating Pornography: Recent Legal Trends' (1982) 34 Land Use L \& Zoning Dig 4

Provided by:

Cleveland-Marshall College of Law Library

-- Your use of this HeinOnline PDF indicates your acceptance of HeinOnline's Terms and Conditions of the license agreement available at https://heinonline.org/HOL/License

-- The search text of this PDF is generated from uncorrected OCR text.

-- To obtain permission to use this article beyond the scope of your license, please use: Copyright Information

Use QR Code reader to send PDF to your smartphone or tablet device 